\title{
Sandfly fauna (Diptera: Psychodidae) from caves in the state of Rondônia, Brazil
}

\author{
Fauna de flebotomíneos (Diptera: Psychodidae) em cavernas do estado de Rondônia, Brasil \\ Guilherme Maerschner Ogawa ${ }^{1 *}$; Antonio Marques Pereira Júnior ${ }^{2,3}$; Fábio Resadore ${ }^{3}$; \\ Ricardo de Godoi Mattos Ferreira ${ }^{3}$; Jansen Fernandes Medeiros ${ }^{3}$; Luis Marcelo Aranha Camargo ${ }^{4}$
}

\author{
${ }^{1}$ Division of Parasitological Diseases and Malaria, Center for Global Health, Centers for Disease Control and Prevention, Atlanta, \\ GA, USA \\ ${ }^{2}$ Fundação Universidade Federal de Rondônia - UNIR, Porto Velho, RO, Brasil \\ ${ }^{3}$ Fundação Oswaldo Cruz - FIOCRUZ Rondônia, Porto Velho, RO, Brasil \\ ${ }^{4}$ Instituto de Ciências Biomédicas, Universidade de São Paulo - USP, Monte Negro, RO, Brasil
}

Received November 17, 2015

Accepted February 11, 2016

\begin{abstract}
This study had the aim of ascertaining the sandfly fauna and possible presence of Leishmania in these insects, collected in caves in the state of Rondônia, Brazil. Collections were conducted in eight caves located in two different areas of this state. Leishmania in the sandflies collected was detected using the polymerase chain reaction (PCR). This was the first study on sandflies from caves in Rondônia and, among the total of 1,236 individuals collected, 24 species and 10 genera were identified. The species Evandromyia georgii was collected for the first time in Rondônia and the most abundant species were Trichophoromyia ubiquitalis with 448 individuals (36.2\%), followed by T. octavioi with 283 (22.9\%) and E. georgii with 179 (14.5\%). For the PCR, 17 pools were analyzed and five pools were positive (for T. auraensis in three pools and for Nyssomyia shawi and N. antunesi in one pool each). The kDNA region was amplified and the presence of Leishmania DNA was confirmed. The sandfly fauna in these caves can be considered diverse in comparison with similar studies in other regions. It may be that some species use caves as a temporary shelter and breeding site, while other species live exclusively in this environment. The detection of Leishmania DNA indicates that this pathogen is circulating in cave environments and that further studies are needed in order to ascertain the risks of infection by leishmaniasis in these locations with high touristic potential.
\end{abstract}

Keywords: Caves, sandflies, Rondônia, Amazon.

\section{Resumo}

O objetivo deste estudo foi conhecer a fauna de flebotomíneos, e possível presença de Leishmania nestes insetos, coletados em cavernas do Estado de Rondônia. As coletas foram realizadas em oito cavernas localizadas em duas áreas diferentes do Estado. A detecçáo de Leishmania nos flebotomíneos foi realizada por reaçáo em cadeia da polimerase (PCR). Este foi o primeiro trabalho com flebotomíneos em cavernas de Rondônia e um total de 1,236 indivíduos foram coletados e identificados em 24 espécies e 10 gêneros. Evandromyia georgii foi coletada pela primeira vez em Rondônia, e as espécies mais abundantes foram Trichophoromyia ubiquitalis com 448 indivíduos (36.2\%) seguida por T. octavioi com 283 (22.9\%) e E. georgii com 179 (14.5\%). No estudo de PCR, 17 pools foram analisados, sendo cinco positivos (T. auraensis - 3, Nyssomyia shawi e N. antunesi - 1 cada). A regiáo do kDNA foi amplificada confirmando a presença de DNA de Leishmania. A fauna de flebotomíneos nestas cavernas foi considerada diversa quando comparada com estudos semelhantes de outras regiôes. É possível que algumas espécies utilizem cavernas como abrigo temporário e local de procriação e outras sejam exclusivas deste ambiente. A detecção de DNA de Leishmania indica que este patógeno está circulando no ambiente cavernícola, sendo necessários mais estudos para conhecer o risco de transmissão de leishmanioses nestes locais com alto potencial turístico.

Palavras-chave: Cavernas, flebotomíneos, Rondônia, Amazônia.

*Corresponding author: Guilherme Maerschner Ogawa. Division of 


\section{Introduction}

Phlebotomine sandflies (Diptera: Psychodidae: Phlebotominae) are insects with worldwide distribution, been described until now 989 species (ALMEIDA et al., 2015). These insects are vectors of numerous pathogens with some species transmitting protozoa of the genus Leishmania Ross (Kinetoplastida, Trypanosomatidae), i.e. the pathogenic agents of leishmaniasis. Afford this, this disease is still considered to be a neglected tropical disease and the northern region of Brazil is a focus for American cutaneous leishmaniasis (ACL) (SINAN, 2015).

In the Amazon region, because of its geographical and ecological characteristics, sandflies have high species diversity in a variety of environments, occurring mainly in forests. Over recent years, sandflies have been found in other environments with human intervention such as fragmented forests and peridomestic areas, thus showing high adaptive capacity (PESSOA et al., 2007; PEREIRA et al., 2015). Caves are environments in which sandflies have been frequently found (ALVES et al., 2011; BARATA \& APOLINÁRIO, 2012; CARVALHO et al., 2013). Inside caves, some factors are favorable to the sandflies' life cycle, like humidity, temperature, organic matter and little or no presence of light (ALENCAR et al., 2011; WILLIAMS, 1976). Adult female sandflies can suck blood from warm-blooded animals, including bats, which recently have been found infected with Leishmania. Thus, bats can act as potential reservoirs and maintain the transmission cycle of leishmaniasis (SAVANI et al., 2010; SHAPIRO et al., 2013).
In some regions, caves have economic and touristic potential and the flow of people through them could be a source of risk of infection by this disease. The only study on the sandfly fauna of caves in the Brazilian Amazonian region was conducted in the municipality of Presidente Figueiredo, state of Amazonas (ALVES et al., 2011). In the state of Rondônia, there are very few studies about these insects and none relating to cave environments (BIANCARDI et al., 1982; GIL et al., 2003, 2009; GALARDO et al., 2015; TELES et al., 2013). Therefore, the present study was the first project conducted in Rondônia with the aims of studying sandfly fauna in caves and ascertaining whether any proven or potential vectors of leishmaniasis were present in caves.

\section{Material and Methods}

\section{Study area}

Eight caves in the state of Rondônia were visited between November 2013 and January 2015 (Table 1). The caves are located in two different areas: one group in the north (municipality of Porto Velho) and the other in the south (municipality of Pimenta Bueno) (Figure 1). In the northern area, collections were made in December 2013 and July 2014, and in the southern area, this was done in April 2014 and October 2014. In each cave, sandflies were caught on two occasions: one during the rainy season (November-April) and the other during the dry season

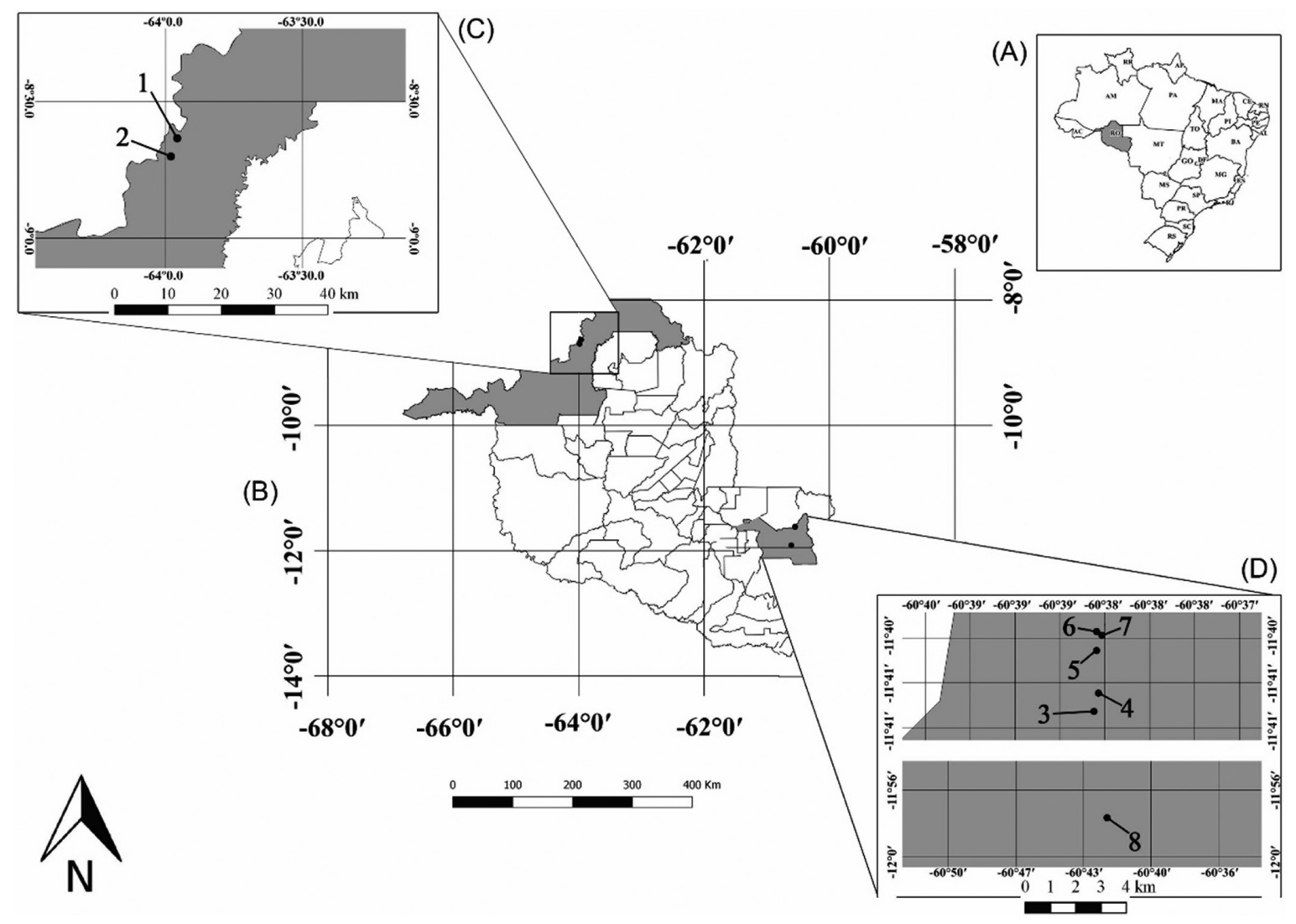

Figure 1. Caves in the state of Rondônia. (Porto Velho Municipality: 1- Sr. Careca; 2- Cachoeira; Pimenta Bueno Municipality; 3- Calcario 1; 4-Calcário 2; 5-Cuica 1; 6-Cuica 2; 7 -Cuica 3 and 8-Morcegos. 
Table 1. Sandfly fauna collected in caves in the municipalities of Porto Velho and Pimenta Bueno, state of Rondônia, Brazil, between 2013 and 2015 .

\begin{tabular}{|c|c|c|c|c|c|c|c|c|c|c|c|c|c|}
\hline \multirow{2}{*}{ Species name } & Careca & Cachoeira & Cuica 1 & Cuica 2 & Cuica 3 & Calcario 1 & Calcario 2 & Morcegos & \multicolumn{5}{|c|}{ Total } \\
\hline & \multicolumn{8}{|c|}{$\hat{\delta} / 9$} & $\hat{0}$ & q & Dry & Rainy & Total \\
\hline B. reducta ${ }^{(C)}$ & $0 / 5$ & $0 / 3$ & - & - & - & - & - & - & 0 & 8 & 5 & 3 & 8 \\
\hline E. brachyphalla & - & - & - & - & - & $1 / 0$ & - & - & 1 & 0 & 1 & 0 & 1 \\
\hline E. georgii $(A)$ & $0 / 178$ & - & - & - & - & $0 / 1$ & - & - & 0 & 179 & 2 & 177 & 179 \\
\hline E. sp. & - & - & - & - & - & $1 / 0$ & - & - & 1 & 0 & 0 & 1 & 1 \\
\hline L. sp. & $0 / 1$ & - & - & - & - & - & - & - & 0 & 1 & 1 & 0 & 1 \\
\hline M. pilosa & $2 / 0$ & - & - & - & - & - & - & - & 2 & 0 & 0 & 2 & 2 \\
\hline N. anduzei $i^{(C)}$ & $4 / 0$ & $2 / 6$ & - & - & - & $0 / 2$ & - & - & 6 & 8 & 8 & 6 & 14 \\
\hline$N$. antunesi $i^{(B, C)}$ & $0 / 3$ & & & $0 / 1$ & $0 / 1$ & $0 / 2$ & $0 / 1$ & $0 / 3$ & 0 & 11 & 2 & 10 & 11 \\
\hline N. richardwardi & $0 / 1$ & - & - & - & - & - & - & - & 0 & 1 & 0 & 1 & 1 \\
\hline N. umbratilis ${ }^{(C)}$ & $0 / 3$ & $0 / 2$ & - & - & - & - & - & - & 0 & 5 & 5 & 0 & 5 \\
\hline N. shawi $i^{(B)}$ & - & $0 / 39$ & - & $0 / 4$ & - & - & - & - & 0 & 43 & 43 & 0 & 43 \\
\hline N. whitmani ${ }^{(C)}$ & $1 / 0$ & - & $1 / 0$ & - & - & - & - & - & 2 & 0 & 2 & 0 & 2 \\
\hline N. yuilli yuilli ${ }^{(C)}$ & - & - & $0 / 1$ & - & - & - & - & - & 0 & 1 & 0 & 1 & 1 \\
\hline P. abunaensis & - & - & - & - & - & - & - & $0 / 1$ & 0 & 1 & 1 & 0 & 1 \\
\hline P. lutziana & $1 / 0$ & - & - & - & - & - & - & - & 1 & 0 & 1 & 0 & 1 \\
\hline P. scaffi & - & - & - & $1 / 0$ & - & - & - & - & 1 & 0 & 0 & 1 & 1 \\
\hline P. gruta* & $0 / 12$ & - & - & - & - & $0 / 1$ & - & - & 0 & 13 & 0 & 13 & 13 \\
\hline P. odax & $0 / 1$ & - & - & - & - & - & - & - & 0 & 1 & 0 & 1 & 1 \\
\hline P. amazonensis ${ }^{(C)}$ & $0 / 1$ & - & - & - & - & - & - & - & 0 & 1 & 0 & 1 & 1 \\
\hline P. davisi ${ }^{(C)}$ & - & - & - & - & - & - & $0 / 1$ & - & 0 & 1 & 0 & 1 & 1 \\
\hline P. geniculatus & $1 / 0$ & - & - & - & - & - & - & - & 1 & 0 & 0 & 1 & 1 \\
\hline S. sordellii & $6 / 24$ & & $2 / 0$ & $1 / 0$ & $1 / 0$ & & $0 / 14$ & $2 / 8$ & 12 & 46 & 32 & 16 & 58 \\
\hline S. sp. & $0 / 3$ & - & - & - & - & - & - & - & 0 & 3 & 3 & 0 & 3 \\
\hline S. servulolimai & $0 / 1$ & - & - & - & - & - & - & - & 0 & 1 & 0 & 1 & 1 \\
\hline T. auraensis ${ }^{(B, C)}$ & $2 / 76$ & $0 / 41$ & $0 / 2$ & - & $0 / 2$ & $0 / 6$ & $0 / 8$ & $0 / 17$ & 2 & 152 & 2 & 152 & 154 \\
\hline T. octavioi & $65 / 19$ & $65 / 103$ & $2 / 0$ & - & - & - & $9 / 0$ & $8 / 12$ & 149 & 134 & 145 & 110 & 283 \\
\hline T. ubiquitalis ${ }^{(C)}$ & $138 / 297$ & $0 / 6$ & $1 / 0$ & - & - & $0 / 2$ & $1 / 0$ & $1 / 2$ & 141 & 307 & 0 & 448 & 448 \\
\hline Total & $220 / 625$ & $67 / 200$ & $6 / 3$ & $2 / 5$ & $1 / 3$ & $2 / 14$ & $10 / 24$ & $11 / 43$ & 319 & 917 & 254 & 945 & 1,236 \\
\hline
\end{tabular}

*species registered only in caves; ${ }^{\left({ }^{2}\right)}$ first record in the state of Rondônia; ${ }^{(b)}$ detected with Leishmania DNA; ${ }^{(c)}$ proven and putative vectors in Brazil (ARAÚJO PEREIRA et al., 2014; ARIAS et al., 1985; AZEVEDO et al., 2008; FREITAS et al., 1989; GIL et al., 2003; LAINSON et al., 1976, 1979; RANGEL \& LAINSON, 2009; SILVEIRA et al., 1991; 2002). B.= Bichromomyia, E.= Evandromyia, $L .=$ Lutzomyia, $M .=$ Micropygomyia, $N .=$ Nyssomyia, $P=P$ sathyromyia,$P .=P i n t o m y i a$, P.= Psychodopygus, S. = Sciopemyia,,.$=$ Trichophoromyia .

(May-October). To detect Leishmania DNA in sandflies using the polymerase chain reaction (PCR), additional collections were made in the northern area between January 2015 and June 2015.

In the north, the cave walls are made of laterite, while in the south they are made of limestone (CECAV, 2008). All the caves are surrounded by forest, with little human presence. The caves in the north (Sr. Careca and Cachoeira) are both located in private areas. The Cachoeira cave is located on a farm, but is in an area with secondary rainforest. This cave received its name because the entrance is behind a waterfall, and the entire cave is in a photic zone. The Sr. Careca cave is 100 meters long and the entrance is a hole in the ground. Its photic area is about 15 meters long, and this cave is L-shaped and has another entrance on the curve. The caves in the south can be separated into three groups. The Cuica 1, 2 and 3 caves are located in dense primary forest: they are small and all have human access only in the photic zone. The Calcario 1 and 2 caves are located along the course of a stream. The Calcario 1 cave is about 50 meters long and the stream flows through the cave, which has two entrances and is entirely within the light zone. The Calcario 2 cave is long, with more than 150 meters accessible by humans, but after 15-20 meters, light is no longer present. Both groups (Cuica and Calcario) are located in a limestone mining area, and some caves in the area have already been destroyed by this activity. The Morcegos cave is located in an area with typical Cerrado forest, and a stream passes inside this cave. This cave is about 80 meters long and has multiple openings with no aphotic zone.

Collections were made using CDC light traps, which were installed at a height of 1.5 meters from the ground over a 48 -hour period. Traps were installed at the entrances of the caves, at every 10 meters. Four traps were used in only one cave (Sr. Careca cave); three traps in three caves (Cachoeira, Calcario 2 and Morcegos) and two traps in four caves (Calcario 1, Cuica1, Cuica 2 and Cuica 3).

After 48 hours, the traps were removed and the insects were placed in tubes with $70 \%$ alcohol and taken to the Entomology Laboratory, Fiocruz, municipality of Porto Velho. The sandflies were mounted as described by Young \& Duncan (1994), except the females that only head and three last segments were mounted and the body was directed molecular analysis. They were identified and taxonomical nomenclature was assigned in accordance with 
Galati (2003). The generic abbreviations followed the proposal of Marcondes (2007).

\section{Molecular detection of Leishmania DNA species}

Females were grouped in pools (2-20 specimens) according to species and location. DNA was extracted by means of the DNeasy ${ }^{\oplus}$ Blood and Tissue Kit (Qiagen), and this was used in Polymerase Chain Reaction (PCR) to detect Leishmania DNA. Positive control was a strain of $L$. (L.) amazonensis (IOCL 575) and negative controls were males of sandflies in each PCR. The PCR for the kinetoplast DNA minicircle (kDNA) that was shared by all Leishmania species was done using primers 5'-GGG(G/T) AGGGGCGTTCT(G/C)CGAA-3' and 5' (G/C)(G/C)(G/C) (A/T)CTAT(A/T)TTACACCAACCCC-3' (OLIVEIRA et al., 2005). In this reaction, $18.7 \mu \mathrm{L}$ of ultrapure $\mathrm{H}_{2} \mathrm{O}, 2.5 \mu \mathrm{L}$ of Go Taq green buffer, $0.75 \mu \mathrm{L}$ of $\mathrm{MgCl}_{2}(2 \mathrm{mM}), 0.38 \mu \mathrm{L}$ of the primers $(1 \mu \mathrm{mol}), 0.5 \mu \mathrm{L}$ of dNTPs $(0.2 \mathrm{mM}) ; 0.25 \mu \mathrm{L}$ of Taq polymerase (Invitrogen) $(1.25 \mathrm{U})$ and $3 \mu \mathrm{L}$ of template DNA were used. The thermal conditions were applied as described by Oliveira et al. (2005).

The positive pools in the first reaction were analyzed for heat shock protein $70(h s p 70)$ to determinate Leishmania at the species level. The primers used were $\mathrm{Hsp} 70 \mathrm{cF}$ 5'-GGACGAGATCGAGCGCATGGT-3' and Hsp70cR 5'-TCCTTCGACGCCTCCTGGTTG-3' (GRAÇA et al., 2012). This reaction was done with $36.25 \mu \mathrm{L}$ of $\mathrm{H}_{2} \mathrm{O}, 5 \mu \mathrm{L}$ of buffer, $1.5 \mu \mathrm{L}$ of $\mathrm{MgCl}_{2}(2 \mathrm{mM}), 1 \mu \mathrm{L}$ of each primer $(1 \mu \mathrm{mol})$, $2 \mu \mathrm{L}$ of dNTPs $(0.2 \mathrm{mM}), 0.5 \mu \mathrm{L}$ of Taq polymerase (Invitrogen) $(1.25 \mathrm{U})$ and $5 \mu \mathrm{L}$ of extracted DNA. The samples were placed in a thermocycler (Veriti; Applied Biosystems ${ }^{\circ}$ ) with an initial denaturation at $94^{\circ} \mathrm{C}$ for 4 minutes, followed by 33 cycles of $94^{\circ} \mathrm{C}$ for 15 seconds (denaturation), $58^{\circ} \mathrm{C}$ for 30 seconds (annealing) and $72{ }^{\circ} \mathrm{C}$ for 30 seconds (extension), and with a final extension of $72^{\circ} \mathrm{C}$ for 10 minutes (PEREIRA et al., 2015).

DNA from male sandflies was used as a negative control for each PCR. The products were viewed and documented on $2 \%$ agarose gel stained with GelRed, using an ImageQuant ${ }^{\mathrm{TM}}$ LAS 4000 viewer.

\section{Statistical analysis}

The data were grouped in an Excel file and descriptive statistics were performed using this software. The Shannon index $\left(\mathrm{H}^{\prime}\right)$ was used to calculate the diversity between sandflies collected in the north or south and in the rainy or dry season (CARVALHO et al., 2013). To assess the prevalence of natural infection of sandflies by Leishmania, pool screening was applied (MARTÍN-SÁNCHEZ et al., 2006).

\section{Environmental clearance}

This study was approved by the National Center for Cave Research and Conservation (Centro Nacional de Pesquisa and Conservação de Cavernas, CECAV) of the Chico Mendes Institute for Biodiversity Conservation (Instituto Chico Mendes de Conservação da Biodiversidade, ICMBio), under number 39682-1/2013.

\section{Results}

A total of 1,236 individuals were collected (Table 1), including 917 females (74.1\%) and 319 males (25.9\%), divided into 24 species and 10 genera. Bichromomyia Artemiev (1 spp.), Evandromyia Mangabeira (2 spp.), Lutzomyia França (not identified at species level), Micropygomyia Barretto (1 spp.), Nyssomyia Barretto (7 spp.), Pintomyia Costa Lima (2 spp.), Psathyromyia Barretto (3 spp.), Psychodopygus Mangabeira (3 spp.), Sciopemyia Barretto (2 spp.) and Trichophoromyia Barretto (3 spp.). The species Evandromyia georgii was collected for the first time in Rondônia. The most abundant genus was Trichophoromyia, with three species and 885 individuals ( $71.6 \%$ of the total). The most abundant species was Th. ubiquitalis with 448 individuals (36.2\%) followed by T. octavioi with 283 (22.9\%) and E. georgii with 179 (14.5\%). The majority of the individuals $(945 ; 78.8 \%)$ were collected during the rainy season. The Sr. Careca cave was the one with the highest number of species and individuals collected (19 species; 845 individuals). Approximately $90 \%$ of the individuals were collected in the northern region of the state.

The Shannon index for general fauna was 2.24. Comparison between data from the two regions showed that there was a higher diversity in the south (2.72) than in the north (1.97) and few differences between rainy and dry seasons (1.58 vs. 1.96).

For PCR, 206 females were grouped into 17 pools (T. auraensis and T. octavioi, four each; Th. ubiquitalis and N. shawi, two each; and Bichromomyia reducta, E. georgii, N. anduzei, N. antunesi and Sciopemyia sordellii, one each). Of these, five pools (T. auraensis, three pools; and $N$. shawi and $N$. antunesi, one pool each) were amplified in the kDNA region and the presence of Leishmania DNA was confirmed (Figure 2). Unfortunately, none were positive in the $h s p 70$ region. The minimum prevalence of infection for T. auraensis was $0.94 \%(95 \% \mathrm{CI}=0.21-0.94-1.85)$.

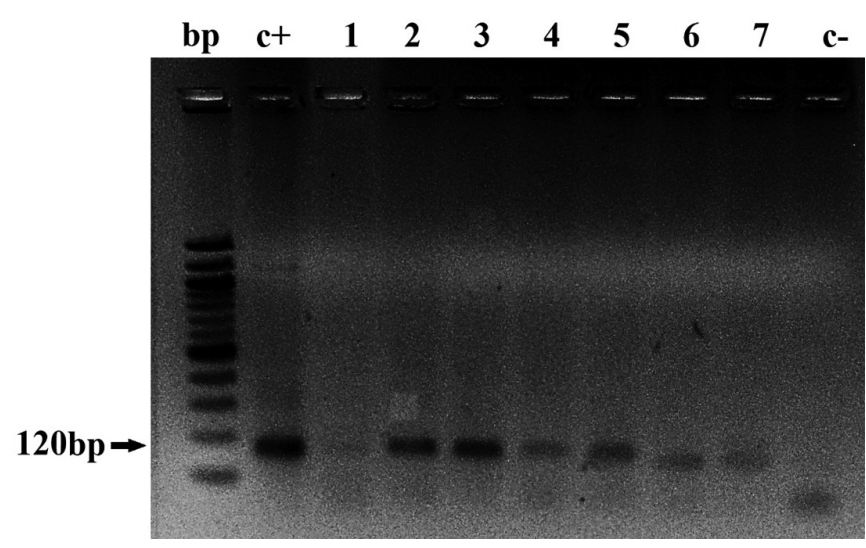

Figure 2. Positive samples for Leishmania sp. in the kDNA PCR Products were visualized on $2 \%$ agarose gel stained with GelRed. Molecular marker pb; 100 base pair ladder (Invitrogen), C+: Leishmania amazonensis (positive control), 1: N. shawi, 2-4: T. auraensis, 5: N. shawi, 6: N. antunesi,7: S. sordellii; samples., C-: negative control. 


\section{Discussion}

This was the first study on sandfly fauna in caves in the state of Rondônia and the second in the northern region of Brazil. It demonstrates that this environment is still very poorly described with regard to the invertebrate fauna, for which the only descriptions that exist are in relation to tick species (ALVES et al., 2011; LABRUNA et al., 2008; NAVA et al., 2010). There are more than fifteen known caves in Rondônia, and this number may be much higher. However, almost half of the caves on the official list are inaccessible to humans or they are flooded throughout the year, which complicate entomological studies (CECAV, 2008).

The sandfly fauna found in these caves in Rondônia was similar in composition to some species found by Alves et al. (2011), who found 15 species in caves in the municipality of Presidente Figueiredo, state of Amazonas. In Minas Gerais, Barata \& Apolinário (2012) collected 17 species, and Carvalho et al. (2013) collected 29 species, thus demonstrating that caves are rich environments for these insects. The majority of the species collected in Rondônia have already been found in other studies, and they are typical in the Amazon environment (ALVES et al., 2011; PEREIRA et al., 2015; SILVA et al., 2014). Some species have wider distribution in the Amazon region, such as Nyssomyia whitmani, Sciopemyia sordellii and Psathyromyia lutziana (CASTELLÓN, 2009; GIL et al., 2003, 2009; SILVA et al., 2014). In our study, nine species occurred only in the northern area of Rondônia: Bichromomyia reducta, Evandromyia georgii, Micropygomyia pilosa, Nyssomyia richardwardi, Nyssomyia umbratilis, Psathyromyia lutziana, Psychodopygus amazonensis, Psychodopygus geniculatus and Pintomyia odax. However, Evandromyia brachyphalla, Psathyromyia abunaensis, Psychodopygus davisi and Psathyromyia scaffi were collected only in the south; these species have been found in other places in the Amazon region (GIL et al., 2009; PEREIRA et al., 2015). The species Psychodopygus davisi, E georgii, Sciopemyia sordellii, Nyssomyia umbratilis and Micropygomyia pilosa had already been reported in caves by Alves et al. (2011).

Furthermore, the present study provides the record of Pintomyia gruta and E. georgii in the state of Rondônia. Pintomyia gruta was found by Galardo et al. (2015) in Rondônia but the authors do not mention this species as a new record for Rondônia. This species had been exclusively found in caves in Serra do Carajás, Pará (RYAN, 1986), which until now was the only environment associated with this species. Regarding E. georgii, its type locality is in the municipality of Oriximiná, state of Pará (RYAN, 1986), but this species was described only in 2002 (FREITAS \& BARRETT, 2002) based on specimens that had previously been identified as Evandromyia begonae (Ortiz \& Torrez), and because of errors in identification, it may be that its real distribution has been underestimated. This species has already been found in Roraima, Amazonas and Pará, which are all states in the Brazilian Amazon region (FREITAS \& BARRETT, 2002; GAMA et al., 2010; RYAN, 1986). The finding of these two species increases the number of sandflies registered in Rondônia: recently, Galardo et al. (2015) elevated the number of species in Rondônia to 118 and, with our findings, this number is updated to 120 species.
In general, most of the species collected in the present study are commonly found in open areas (GALARDO et al., 2015; GIL et al., 2003, 2009; PEREIRA et al., 2015). However, the presence of these species inside caves may not be accidental, and is probably due to the presence of food resources and shelter, even if temporarily, as suggested in some other studies (ALVES et al., 2011; WILLIAMS, 1976). Sandfly studies conducted inside caves, paired with collections in surrounding areas, have usually found the same species composition but differences in the abundance of species (CARVALHO et al., 2013; GALATI et al., 2010).

The total number of individuals collected, which was an average of 24.5 individuals per trap, can be considered to be low, in comparison with collections made in open areas and in caves in other regions (GALATI et al., 2010). In a study conducted in caves in the state of Minas Gerais, Carvalho et al. (2013) collected 5,255 individuals over a 24-month period using five traps, with an average of 43 individuals per trap. In a study in caves in the state of Amazonas, Alves et al. (2011) also collected an average of 43 individuals per trap. However, in a study in caves in the state of São Paulo, Galati et al. (2010) found an average of 4.48 individuals per trap. According to these last authors, high altitude, high humidity and low temperatures are the possible explanations for the low abundance in that area. In the case of Rondônia, high humidity could be a limiting factor for sandfly collections, along with rainfall, which may also have an influence in caves in Rondônia. Tropical storms are quite common in this area, and they can cause flooding, which washes the ground of the caves, thereby removing guano and other substrates used by sandflies as a breeding site. This might also affect the number of individuals collected (ALVES et al., 2011; CARVALHO et al., 2013). Species have different preferences, but collections made right after the beginning of the rainy season usually result in higher numbers of specimens than in collections made at the end of the rainy season and in the dry season (BARATA \& APOLINÁRIO, 2012). Nonetheless, there have been reports of high abundance of these insects at the end of the rainy season (GALARDO et al., 2015).

In general, the Shannon index for this study showed high diversity, and this is a common finding in the Amazon region (GIL et al., 2003; PEREIRA et al., 2015; SILVA et al., 2014). The index showed higher diversity in the south, probably because of the large number of individuals of the same species in the north, such as T. ubiquitalis. The diversity found was higher than among sandflies collected in caves in other Brazilian regions and also the Amazon region. Galati et al. (2010) found an index of 1.90. In a study in three caves in the state of Amazonas, Alves et al. (2011) reported an index of 0.96. Carvalho et al. (2013) calculated a Shannon index of between 0.72 and 0.83 . Caves are usually a more selective environment and they may be strongly influenced by the surrounding areas (GALATI et al., 2006). Human intervention, such as exploitation of environments, has a direct influence on sandfly fauna (PESSOA et al., 2007). In relation to the caves of Rondônia, the surrounding areas are still well preserved and they are not frequently used as a tourist attraction, which may contribute to the values observed.

The potential touristic use of caves is very high and this activity can cause a decrease in sandfly diversity and an increase in human contact with leishmaniasis vectors (ALVES et al., 2011; BARATA 
\& APOLINÁRIO, 2012). In this study, we found eight species that have already been correlated with leishmaniasis transmission: Bichromomyia reducta was found naturally infected with Leishmania (Leishmania) amazonensis Lainson \& Shaw in state of Rondônia (FREITAS et al., 1989). Nyssomyia anduzei is considered a secondary vector but with a few importance in transmission of ACL (LAINSON et al., 1976; RANGEL \& LAINSON, 2009). Nyssomyia umbratilis is a vector carrying $L$. $(V$.) guyanensis to humans in French Guiana and also in Brazil, Colombia, Guyana, Suriname and Venezuela (RANGEL \& LAINSON, 2009). Nyssomyia whitmani was found infected with $L$. $(V$.) braziliensis in Ceará (AZEVEDO et al., 1990) and reported with Leishmania sp. in Pará probably $L .(V$.$) guyanensis/L. (V$.$) shawi (JENNINGS et al.,$ 2014; LAINSON et al., 1979) and is considered to be a putative vector. Nyssomyia yuilli yuilli was found naturally infected in Brazil, but without identification of the flagellate forms, and therefore transmission was only suspected (ARIAS et al., 1985). Psychodopygus amazonensis was correlated with one individual infected with a Leishmania parasite that further was described as L. $(V$.) naiff Lainson \& Shaw in Pará (LAINSON et al., 1973; RANGEL \& LAINSON, 2009). Trichophoromyia ubiquitalis is a proven vector of $L$. $(V$.) lainsoni Silveira, Shaw, Braga \& Ishikawa in Brazil (SILVEIRA et al., 1991) and was detected in state of Amazonas with Leishmania DNA (SILVA et al., 2014; PEREIRA et al., 2015).

We detected Leishmania DNA in $N$. antunesi, $N$. shawi and $T$. auraensis, but it was not possible to identify the species probably because the low concentration of DNA. Nyssomyia antunesi has been associated to different environments with anthropic activities in some studies in the northern region of Brazil (AZEVEDO et al., 2008; GIL et al., 2003; PEREIRA et al., 2015). This species was found with Leishmania sp. (THIES et al., 2013) and is a vector for $L$. (V.) lindenbergi Silveira, Ishikawa, Souza \& Lainson in Brazil (SILVEIRA et al., 2002). Nyssomyia shaw i is considered to be a suspected vector of $L$. (V.) braziliensis in Bolivia (BUSTAMANTE et al., 2012). Trichophoromyia auraensis was found with $L .(V$.$) lainsoni and L .(V$.$) braziliensis$ in Madre de Dios, Peru (VALDIVIA et al., 2012). This species is different from Trichophoromyia ruifreitasi (OLIVEIRA et al., 2015) on the males genitalia, $T$. auraensis has a paramere with a dorsal lobe that begins in the apex and ends at the half of structure while T. ruifreitasi has a subtriangular paramere with a discrete lobe dorsal (OLIVEIRA et al., 2015). Also, Th. auraensis has been found in abundance in the state of Acre (AZEVEDO et al., 2008; ARAUJO-PEREIRA et al., 2014), thus showing the role of T. auraensis in maintaining the circulation of Leishmania species, despite of its unclear vector competence.

According to our findings, the sandfly fauna in caves was considered to be diverse even when compared with studies in other regions. Some species may be using caves as a temporary shelter and breeding site, while other species live exclusively in this environment. The detection of Leishmania DNA indicates that this pathogen circulates in the cave environment and further studies are necessary in order to estimate the risks of infection with leishmaniasis in these locations with high touristic potential.

\section{References}

Alencar RB, Queiroz RG, Barrett TV. Breeding sites of phlebotomine sand flies (Diptera: Psychodidae) and efficiency of extraction techniques for immature stages in terra-firme forest in Amazonas State, Brazil. Acta Trop 2011; 118(3): 204-208. http://dx.doi.org/10.1016/j.actatropica.2010.10.012. PMid:21457701.

Almeida PS, Andrade AJ, Sciamarelli A, Raizer J, Menegatti JA, Hermes SCNM, et al. Geographic distribution of phlebotomine sandfly species (Diptera: Psychodidae) in Central-West Brazil. Mem Inst Oswaldo Cruz 2015; 110(4): 551-559. http://dx.doi.org/10.1590/0074-02760140462. PMid:26018450.

Alves VR, Freitas RA, Santos FL, Barrett TV. Diversity of sandflies (Psychodidae: Phlebotominae) captured in sandstone caves from Central Amazonia, Brazil. 2011. Mem Inst Oswaldo Cruz 2011; 106(3): 353-359. http://dx.doi.org/10.1590/S0074-02762011000300016. PMid:21655825.

Araujo-Pereira T, Fuzari AA, Andrade JDA Fo, Pita-Pereira D, Britto C, Brazil RP. Sand fly fauna (Diptera: Psychodidae: Phlebotominae) in an area of leishmaniasis transmission in the municipality of Rio Branco, state of Acre, Brazil. Parasit Vectors 2014; 7(1): 360. http://dx.doi. org/10.1186/1756-3305-7-360. PMid:25103985.

Arias JR, Miles MA, Naiff RD, Povoa MM, Freitas RA, Biancardi CB, et al. Flagellate infections of Brazilian sand flies (Diptera: Psychodidae): Isolation in vitro and biochemical identification of Endotrypanum and Leishmania. Am J Trop Med Hyg 1985; 34(6): 1098-1108. PMid:3938924.

Azevedo ACR, Costa SM, Pinto MCG, Souza JL, Cruz HC, Vidal J, et al. Studies on the sandfly fauna (Diptera: Psychodidae: Phlebotominae) from transmission areas of American Cutaneous Leishmaniasis in state of Acre, Brazil. Mem Inst Oswaldo Cruz 2008; 103(8): 760-767. http:// dx.doi.org/10.1590/S0074-02762008000800003. PMid:19148413.

Azevedo ACR, Rangel EF, Costa EM, David J, Vasconcelos AW, Lopes UG. Natural infection of Lutzomyia (Nyssomyia) whitmani (Antunes \& Coutinho, 1939) by Leishmania of the braziliensis complex in Baturité, Ceará state, northeast Brazil. Mem Inst Oswaldo Cruz 1990; 85(2): 251. http://dx.doi.org/10.1590/S0074-02761990000200021. PMid:2087162.

Barata RA, Apolinário EC. Sandflies (Diptera: Psychodidae) from caves of the quartzite Espinhaço Range, Minas Gerais, Brazil. Mem Inst Oswaldo Cruz 2012; 107(8): 1016-1020. http://dx.doi.org/10.1590/ S0074-02762012000800009. PMid:23295752.

Biancardi CB, Arias JR, Freitas RA, Castellon EG. The known geographical distribution of sand flies in the state of Rondonia, Brazil (Diptera: Psychodidae). Acta Amazon 1982; 12(1): 167-179.

Bustamante M, Diaz M, Espinoza J, Parrado R, Reithinger R, García AL. Sand fly fauna in Chapare, Bolivia: an endemic focus of Leishmania (Viannia) braziliensis. J Med Entomol 2012; 49(5): 1159-1162. http:// dx.doi.org/10.1603/ME12013. PMid:23025199.

Carvalho GML, Brazil RP, Ramos MCNF, Serra e Meira PCL, Zenóbio APLA, Botelho HA, et al. Ecological aspects of Phlebotomine sandflies (Diptera: Psychodidae) from a cave of the speleological Province of Bambuí, Brazil. PLoS One 2013; 8(10): e77158. http://dx.doi.org/10.1371/journal. pone.0077158. PMid:24130847.

Castellón EG. Lutzomyia sandflies in the Brazil Amazon basin (Diptera: Psychodidae). Manaus: INPA; 2009.

Centro Nacional de Pesquisa e Conservação de Cavernas - CECAV. Base de dados geoespecializados das cavernas do Brasil [online]. Brasília: 
CECAV; 2008 [cited 2015 May 7]. Available from: http://www.icmbio. gov.br/cecav/downloads/mapas.html

Freitas RA, Barrett TV, Naiff RD. Lutzomyia reducta Feliciangeli et al., 1988, a host of Leishmania amazonensis, sympatric with two other members of the Flaviscutellata complex in southern Amazonas and Rondônia, Brazil (Diptera: Psychodidae). Mem Inst Oswaldo Cruz 1989; 84(3): 363-369. http://dx.doi.org/10.1590/S0074-02761989000300011.

Freitas RA, Barrett TV. Descriptions of Lutzomyia (Evandromyia) georgii n. sp. and a Synopsis of the series infraspinosa (Diptera: Psychodidae). Mem Inst Oswaldo Cruz 2002; 97(2): 239-245. http://dx.doi.org/10.1590/ S0074-02762002000200017. PMid:12016450.

Galardo AKR, Galardo CD, Silveira GA, Ribeiro KAN, Hijjar AV, Oliveira LL, et al. Phlebotominae sand flies (Diptera: Psychodidae): potential vectors of American cutaneous leishmaniasis agents in the area associated with the Santo Antônio Hydroelectric System in Western Amazonian Brazil. Rev Soc Bras Med Trop 2015; 48(3): 265-271. http:// dx.doi.org/10.1590/0037-8682-0088-2015. PMid:26108003.

Galati EAB, Marassá AM, Gonçalves-Andrade RM, Consales CA, Bueno EFM. Phlebotomines (Diptera, Psychodidae) in the Ribeira Valley Speleological Province - 1. Parque Estadual Intervales, state of São Paulo, Brazil. Rev Bras Entomol 2010; 54(2): 311-321. http://dx.doi. org/10.1590/S0085-56262010000200015.

Galati EAB, Nunes VLB, Boggiani PC, Dorval MEC, Cristaldo G, Rocha HC, et al. Phlebotomines (Diptera: Psychodidae) in forested areas of the Serra da Bodoquena, state of Mato Grosso do Sul, Brazil. Mem Inst Oswaldo Cruz 2006; 101(2): 175-193. http://dx.doi.org/10.1590/ S0074-02762006000200010. PMid:16830711.

Galati EAB. Morfologia e taxonomia. In: Rangel EF, Lainson R, editors. Flebotomíneos do Brasil. Rio de Janeiro: Fiocruz; 2003. p. 23-51.

Gama JL No, Freitas RA, Baima JM, Passos MAB. Fauna flebotomínica (Diptera: Psychodidae) da Serra do Tepequém, Município de Amajari, Estado de Roraima, Brasil. Rev Pan-Amaz Saúde 2010; 1(2): 131-136. http://dx.doi.org/10.5123/S2176-62232010000200016.

Gil LHS, Araújo MS, Villalobos JM, Camargo LMA, Ozaki LS, Fontes CJF, et al. Species structure of sand fly (Diptera: Psychodidae) fauna in the Brazilian western Amazon. Mem Inst Oswaldo Cruz 2009; 104(7): 955-959. http://dx.doi.org/10.1590/S0074-02762009000700002. PMid:20027459.

Gil LHS, Basano SA, Souza AA, Silva MGS, Barata I, Ishikawa EA, et al. Recent observations on the sand fly (Diptera: Psychodidae) fauna of the State of Rondônia, Western Amazônia, Brazil: the importance of Psychodopygus davisi as a vector of zoonotic cutaneous leishmaniasis. Mem Inst Oswaldo Cruz 2003; 98(6): 751-755. http://dx.doi.org/10.1590/ S0074-02762003000600007. PMid:14595450.

Graça GC, Volpini AC, Romero GAS, Oliveira MP No, Hueb M, Porrozzi $\mathrm{R}$, et al. Development and validation of PCR-based assays for diagnosis of American cutaneous leishmaniasis and identification of the parasite species. Mem Inst Oswaldo Cruz 2012; 107(5): 664-674. http://dx.doi. org/10.1590/S0074-02762012000500014. PMid:22850958.

Jennings YL, Souza AAA, Ishikawa EA, Shaw J, Lainson R, Silveira F. Phenotypic characterzation of Leishmania spp. causing cutaneous leishmaniasis in the lower Amazon region, western Pará state, Brazil, reveals a putative hybrid parasite, Leishmania (Viannia) guyanensis $\mathrm{x}$ Leishmania (Viannia) shawi shawi. Parasite 2014; 21: 39. http://dx.doi. org/10.1051/parasite/2014039. PMid:25083790.

Labruna MB, Terassini FA, Camargo LMA, Brandão PE, Ribeiro AF, Estrada-Peńa A. New reports of Antricola guglielmonei and Antricola delacruzi in Brazil, and a description of a new Argasid species (Acari). J Parasitol 2008; 94(4): 788-792. http://dx.doi.org/10.1645/GE-1447.1. PMid:18576796.

Lainson R, Shaw JJ, Ward RD, Fraiha H. Leishmaniasis in Brazil: IX. Considerations on the Leishmania braziliensis complex: - Importance of sandflies of the genus Psychodopygus (Mangabeira) in the transmission of L. braziliensis braziliensis in north Brazil. Trans R Soc Trop Med Hyg 1973; 67(2): 184-196. http://dx.doi.org/10.1016/0035-9203(73)901430. PMid:4784055.

Lainson R, Shaw JJ, Ward RD, Ready PD, Naiff RD. Leishmaniasis in Brazil: XIII. Isolation of Leishmania from armadillos (Dasypus novemcinctus), and observations on the epidemiology of cutaneous leishmaniasis in north Pará State. Trans R Soc Trop Med Hyg 1979; 73(2): 239-242. http://dx.doi. org/10.1016/0035-9203(79)90225-6. PMid:473314.

Lainson R, Ward RD, Shaw JJ. Letter: Cutaneous leishmaniasis in North Brazil: Lutzomyia anduzei as a major vector. Trans $R$ Soc Trop Med Hyg 1976; 70(2): 171-172. http://dx.doi.org/10.1016/0035-9203(76)902029. PMid:960211.

Marcondes CB. A proposal of generic and subgeneric abbreviations for phlebotomine sandflies (Diptera: Psychodidae: Phlebotominae) of the world. Entomol News 2007; 118(4): 351-356. http://dx.doi.org/10.3157/0013872X(2007)118[351:APOGAS]2.0.CO;2.

Martín-Sánchez J, Gállego M, Barón S, Castillejo S, Morillas-Marquez F. Pool screen PCR for estimating the prevalence of Leishmania infantum infection in sandflies (Diptera: Nematocera, Phlebotomidae). Trans $R$ Soc Trop Med Hyg 2006; 100(6): 527-532. http://dx.doi.org/10.1016/j. trstmh.2005.08.005. PMid:16310236.

Nava S, Venzal JM, Terassini FA, Mangold AJ, Camargo LMA, Labruna MB. Description of a new argasid tick (Acari: Ixodida) from bat caves in Brazilian Amazon. J Parasitol 2010; 96(6): 1089-1101. http://dx.doi. org/10.1645/GE-2539.1. PMid:21158616.

Oliveira AFJ, Teles CBG, Medeiros JF, Camargo LMA, Pessoa FAC. Descripition of Trichophoromyia ruifreitasi, a new phlebotomine species (Diptera, Psychodidae) from Acre State, Brazilian Amazon. ZooKeys 2015; 526(526): 65-73. http://dx.doi.org/10.3897/zookeys.526.6128. PMid:26487825.

Oliveira JGS, Novais FO, Oliveira CI, Cruz AC Jr, Campos LF, Rocha $\mathrm{AV}$, et al. Polymerase chain reaction (PCR) is highly sensitive for diagnosis of mucosal leishmaniasis. Acta Trop 2005; 94(1): 55-59. http://dx.doi. org/10.1016/j.actatropica.2004.12.003. PMid:15777720.

Pereira AM Jr, Teles CBG, Santos APA, Rodrigues MS, Marialva EF, Pessoa FAC, et al. Ecological aspects and molecular detection of Leishmania DNA Ross (Kinetoplastida: Trypanosomatidae) in phlebotomine sandflies (Diptera: Psychodidae) in terra firme and várzea environments in the Middle Solimóes Region, Amazonas State, Brazil. Parasit Vectors 2015; 8(1): 180. http://dx.doi.org/10.1186/s13071-015-0789-2. PMid:25889808.

Pessoa FAC, Medeiros JF, Barrett TV. Effects of timber harvest on phlebotomine sand flies (Diptera: Psychodidae) in a production forest: abundance of species on tree trunks and prevalence of trypanosomatids. Mem Inst Oswaldo Cruz 2007; 102(5): 593-599. http://dx.doi.org/10.1590/ S0074-02762007005000075. PMid:17710304.

Rangel EF, Lainson R. Proven and putative vectors of American cutaneous leishmaniasis in Brazil: aspects of their biology and vectorial competence. Mem Inst Oswaldo Cruz 2009; 104(7): 937-954. http://dx.doi.org/10.1590/ S0074-02762009000700001. PMid:20027458. 
Ryan L. Flebótomos do estado do Pará, Brasil (Diptera: Psychodidae: Phlebotominae). Belém: Instituto Evandro Chagas; 1986. 154 p. n. 1. Documento técnico.

Savani ESMM, Almeida MF, Oliveira Camargo MCG, D'Auria SRN, Silva MMS, Oliveira ML, et al. Detection of Leishmania (Leishmania) amazonensis and Leishmania (Leishmania) infantum chagasi in Brazilian bats. Vet Parasitol 2010; 168(1-2): 5-10. http://dx.doi.org/10.1016/j. vetpar.2009.10.019. PMid:19939568.

Shapiro JT, Costa Lima MS Jr, Dorval MEC, Oliveira França A, Cepa Matos MF, Bordignon MO. First record of Leishmania braziliensis presence detected in bats, Mato Grosso do Sul, southwest Brazil. Acta Trop 2013; 128(1): 171-174. http://dx.doi.org/10.1016/j.actatropica.2013.07.004. PMid:23886850.

Silva TRR, Assis MDG, Freire MP, Rego FD, Gontijo CMF, Shimabukuro PHF. Molecular detection of Leishmania in sand flies (Diptera: Psychodidae: Phlebotominae) collected in the Caititu Indigenous Reserve of the Municipality of Lábrea, State of Amazonas, Brazil. J Med Entomol 2014; 51(6): 1276-1282. http://dx.doi.org/10.1603/ME14025. PMid:26309318.

Silveira FT, Ishikawa EAY, Souza AAA, Lainson R. An outbreak of cutaneous leishmaniasis among soldiers in Belém, Pará State, Brazil, caused by Leishmania (Viannia) lindenbergi n. sp. A new leishmanial parasite of man in the Amazon region. Parasite 2002; 9(1): 43-50. http://dx.doi. org/10.1051/parasite/200209143. PMid:11938695.

Silveira FT, Souza AA, Lainson R, Shaw JJ, Braga RR, Ishikawa EE. Cutaneous leishmaniasis in the Amazon region: natural infection of the sandfly Lutzomyia ubiquitalis (Psychodidae: Phlebotominae) by Leishmania (Viannia) lainsoni in Pará State, Brazil. Mem Inst Oswaldo Cruz 1991; 86(1): 127-130. http://dx.doi.org/10.1590/S0074-02761991000100021. PMid:1842393.
Sistema de informações de agravos de notificação - SINAN. Secretaria de Vigilância em Saúde [online]. 2015 [cited 2015 Jun 1]. Available from: http://dtr2004.saude.gov.br/sinanweb/.

Teles CBG, Basano SA, Zagonel-Oliveira M, Campos JJ, Oliveira AFJ, Freitas RA, et al. Epidemiological aspects of American cutaneous leishmaniasis and phlebotomine sandfly population, in the municipality of Monte Negro, State of Rondônia, Brazil. Rev Soc Bras Med Trop 2013; 46(1): 60-66. http://dx.doi.org/10.1590/0037-868216062013. PMid:23563827.

Thies SF, Ribeiro ALM, Michalsky EM, Miyazaki RD, Fortes-Dias CL, Fontes CJF, et al. Phlebotomine sandfly fauna and natural Leishmania infection rates in a rural area of Cerrado (tropical savannah) in Nova Mutum, State of Mato Grosso in Brazil. Rev Soc Bras Med Trop 2013, 46(3): 293-298. http://dx.doi.org/10.1590/0037-8682-0031-2013. PMid:23856858.

Valdivia HO, De Los Santos MB, Fernandez R, Baldeviano GC, Zorrilla VO, Vera H, et al. Natural Leishmania Infection of Lutzomyia auraensis in Madre de Dios, Peru, detected by a fluorescence resonance energy transfer-based Real-Time Polymerase Chain Reaction. Am J Trop Med Hyg 2012; 87(3): 511-517. http://dx.doi.org/10.4269/ajtmh.2012.11-0708. PMid:22802444.

Williams P. The phlebotomine sandflies (Diptera, Psychodidae) of caves in Belize, Central America. Bull Entomol Res 1976; 65(4): 601-614. http:// dx.doi.org/10.1017/S0007485300006301.

Young DG, Duncan MA. Guide to the identification and geographic distribution of Lutzomyia sand flies in Mexico, the West Indies, Central and South America (Diptera:Psychodidae). Gainesville: American Entomological Institute; 1994. 